\title{
Operating the nickel electrode with hydrogen-lean gases in the molten carbonate electrolysis cell (MCEC)
}

\author{
Lan $\mathrm{Hu}^{*}$, Göran Lindbergh and Carina Lagergren \\ Applied Electrochemistry, Department of Chemical Engineering and Technology, \\ KTH Royal Institute of Technology, SE-100 44 Stockholm, Sweden \\ * Corresponding author: lanhu@kth.se Phone No. +46 (0)8-790 8244
}

\begin{abstract}
If a molten carbonate electrolysis cell (MCEC) is applied for fuel gas production it is important to know the polarization of the nickel electrode when operated at low concentration of hydrogen. Thus, the electrochemical performance of the $\mathrm{Ni}$ electrode was investigated under hydrogen-lean gases containing $1 / 24.5 / 24.5 / 50 \%, 1 / 49.5 / 24.5 / 25 \%, 1 / 24.5 / 49.5 / 25 \%$ and $1 / 49.5 / 49.5 / 0 \% \mathrm{H}_{2} / \mathrm{CO}_{2} / \mathrm{H}_{2} \mathrm{O} / \mathrm{N}_{2}$ in the temperature range of $600-650{ }^{\circ} \mathrm{C}$ and was then compared to the reference case with $25 / 25 / 25 / 25 \%$ $\mathrm{H}_{2} / \mathrm{CO}_{2} / \mathrm{H}_{2} \mathrm{O} / \mathrm{N}_{2}$. The electrochemical measurements included polarization curve coupled with current interrupt, and electrochemical impedance spectroscopy. Polarization resistances of the $\mathrm{Ni}$ electrode obtained by the two different techniques agreed well. For the inlet gases containing low amounts of hydrogen the Ni electrode exhibited higher polarization losses than when using the reference case in the electrolysis cell. The electrochemical impedance measurements showed that both charge-transfer and mass-transfer polarizations were higher for hydrogen-lean gases at all measured temperatures. Except under the condition with $1 / 49.5 / 49.5 \% \mathrm{H}_{2} / \mathrm{CO}_{2} / \mathrm{H}_{2} \mathrm{O}$ at $650{ }^{\circ} \mathrm{C}$, the Ni electrode exhibited lower mass-transfer polarization when compared to the reference case. Furthermore, the mass-transfer polarization was strongly dependent on temperature under $\mathrm{H}_{2}$-lean gases, differing from the reference case when the temperature has almost no effect on mass-transfer polarization. The activation energy for hydrogen production was calculated to be in the range of $69-138 \mathrm{~kJ} \cdot \mathrm{mol}^{-1}$ under all measured gases, indicating that the Ni electrode is under kinetic and/or mixed control in the MCEC.
\end{abstract}

Keywords: hydrogen-lean gases; molten carbonate electrolysis cell; Ni electrode; polarization. 


\section{Introduction}

High-temperature electrolysis technology provides the opportunity for generating fuel gases, such as hydrogen or syngas, in an environmentally friendly way, especially when using renewable energy, e.g. solar energy and/or wind power, as power supply to the electrolysis. Additionally, due to favorable thermodynamic and kinetic conditions high-temperature electrolysis attains higher overall efficiency and requires lower applied voltage than low-temperature electrolysis $[1,2]$. This may decrease the cost of fuel gases, because the electricity consumption is an essential factor for competitive commercialization of the electrolysis technology [3].

Studies on high-temperature water electrolysis have been carried out since the early 1980s but limited only to solid oxide electrolysis cell (SOEC) technology [4]. Much progress on the SOEC technology has been achieved for hydrogen production, for example as regards the electrochemical performance and the durability of the cell and stack, electrode and electrolyte materials, and modeling of SOEC systems [5-9]. Furthermore, the SOEC technology is not only focused on water electrolysis for hydrogen production, but also on co-electrolysis of water and carbon dioxide for syngas and carbon fuels generation [10-14].

However, concerning another high-temperature electrolysis technology, the molten carbonate electrolysis cell (MCEC), only a few studies have been made so far. The possibility of electrolysis in molten carbonate salts has been evidenced [15-19], but was initially investigated for carbon dioxide capture by converting $\mathrm{CO}_{2}$ into $\mathrm{CO}$ and/or $\mathrm{C}$. Peelen et al. [15] studied the electrochemical reduction of $\mathrm{CO}_{2}$ into $\mathrm{CO}$ on a gold flag electrode in $\mathrm{Li} / \mathrm{K}$ carbonate eutectics at temperatures from 575 to $700{ }^{\circ} \mathrm{C}$. Kaplan et al. $[16,17]$ studied the conversion of $\mathrm{CO}_{2}$ to $\mathrm{CO}$ in a cell operated at $850-900{ }^{\circ} \mathrm{C}$. The cell consisted of a graphite anode and a titanium cathode, and an electrolyte mixture of lithium carbonate and lithium oxide. Chery et al. $[18,19]$ investigated the electrochemical reduction of $\mathrm{CO}_{2}$ on a gold flag or planar disk electrode by using cyclic voltammetry, and also presented thermodynamic calculations focused on the reduction processes $\left(\mathrm{CO}_{2} / \mathrm{CO}, \mathrm{CO}_{2} / \mathrm{C}, \mathrm{CO} / \mathrm{C}, \mathrm{H}_{2} \mathrm{O} / \mathrm{H}_{2}\right.$, and $\left.\mathrm{M}^{+} / \mathrm{M}\right)$ in molten carbonates. However, none of the studies above were performed using porous electrodes. Our previous study [20] has proved the feasibility of operating the molten carbonate electrolysis cell by using conventional fuel cell (MCFC) materials, i.e. the cell components consist of Ni-based porous electrodes and carbonate electrolytes. In this case, the molten carbonate cell could be operated alternatingly as a fuel cell to produce electricity and as an electrolysis cell to generate fuel gases.

For the development of the MCEC technology, it is very important to investigate the process of hydrogen production in molten carbonate salts. In our previous studies $[20,21]$ the gases used for the $\mathrm{Ni}$ electrode still contain a relatively high amount of hydrogen in the MCEC. If the electrochemical cell is mainly applied for fuel gas production, the inlet gases should contain low amounts of hydrogen or even no hydrogen. Therefore, it is an essential issue to determine the Ni electrode polarization in 
this case. The present paper aims to study the polarization losses of the Ni porous electrode in the electrolysis cell when using four different hydrogen-lean gases. The electrochemical performance of the $\mathrm{Ni}$ electrode is investigated by means of polarization curves and electrochemical impedance data and is compared to the reference case with the gas composition $25 / 25 / 25 / 25 \% \mathrm{H}_{2} / \mathrm{CO}_{2} / \mathrm{H}_{2} \mathrm{O} / \mathrm{N}_{2}$.

\section{Experimental}

The electrochemical measurements were carried out in a $3 \mathrm{~cm}^{2}$ laboratory cell unit. The cell has a porous $\mathrm{Ni}-\mathrm{Cr}$ alloy as cathode, and porous $\mathrm{Ni}$, oxidized and lithiated in situ, as anode. The electrodes are separated by a porous $\mathrm{LiAlO}_{2}$ matrix, which also supports the electrolyte, a eutectic mixture of $62 / 38 \mathrm{~mol} \% \mathrm{Li}_{2} \mathrm{CO}_{3} / \mathrm{K}_{2} \mathrm{CO}_{3}$. The current collectors on the cathode and anode sides are made of nickel and stainless steel SS316, respectively. Each current collector has two probes, one for measuring the current and the other for potential measurement. Two reference electrodes, consisting of gold wires in equilibrium with a gas mixture of $33 / 67 \% \mathrm{O}_{2} / \mathrm{CO}_{2}$, are placed in separate chambers filled with the same electrolyte as in the cell. These chambers are connected to the cell through a capillary with a gold plug. A schematic drawing of this laboratory cell set-up is found in Ref. 20.

A gas consisting of $15 / 30 / 55 \% \mathrm{O}_{2} / \mathrm{CO}_{2} / \mathrm{N}_{2}$ was used for the $\mathrm{NiO}$ electrode throughout the experiments. For the Ni electrode five different gas mixtures of $\mathrm{H}_{2} / \mathrm{CO}_{2} / \mathrm{H}_{2} \mathrm{O} / \mathrm{N}_{2}$ were introduced. Table 1 gives the detailed gas compositions, including the reference case (gas 1) and the gases with low $\mathrm{H}_{2}$ concentration (gases 2-5). The concentration of $\mathrm{H}_{2} \mathrm{O}$ in the inlet gases was controlled by the temperature of the water in the humidifier. The gas flow rates for the $\mathrm{Ni}$ and $\mathrm{NiO}$ electrodes were about $150 \mathrm{ml} \cdot \mathrm{min}^{-1}$, while the reference gas had a flow rate of $20 \mathrm{ml} \cdot \mathrm{min}^{-1}$. All the gases used in the experiments are certified gas mixtures from AGA Gas AB, Sweden.

Table 1 The inlet gas compositions for the Ni electrode, in percent.

\begin{tabular}{|c|c|c|c|c|}
\hline Gas No. & $\mathrm{H}_{2} / \%$ & $\mathrm{CO}_{2} / \%$ & $\mathrm{H}_{2} \mathrm{O} / \%$ & $\mathrm{~N}_{2} / \%$ \\
\hline 1 & 25 & 25 & 25 & 25 \\
\hline 2 & 1 & 24.5 & 24.5 & 50 \\
\hline 3 & 1 & 49.5 & 24.5 & 25 \\
\hline 4 & 1 & 24.5 & 49.5 & 25 \\
\hline 5 & 1 & 49.5 & 49.5 & - \\
\hline
\end{tabular}

The electrochemical performance of the Ni electrode was measured by steady-state polarization curves and electrochemical impedance spectroscopy (EIS). These measurements were performed at 600,625 and $650{ }^{\circ} \mathrm{C}$. The polarization data were obtained potentiostatically using a Solartron Interface SI1 287. In order to correct for ohmic losses, the current-interrupt technique was used. The EIS measurements were carried out using a Solartron 1255 FRA and a Solartron Interface SI1287. The frequency spectra 
were recorded in the electrolysis cell mode in the frequency range from $10 \mathrm{mHz}$ to $10 \mathrm{kHz}$ with an amplitude of $10 \mathrm{mV}$. An overpotential of $-0.05 \mathrm{~V}$ was applied at the $\mathrm{Ni}$ electrode to simulate the electrolysis operation.

Post-test analysis using scanning electron microscopy (SEM) was performed to study the microstructure of the Ni electrode. One electrode sample with carbonate and another leached in 50\% acetic acid were examined.

\section{Results and Discussion}

Fig. 1 shows SEM micrographs of the Ni porous electrode used in the electrolysis cell. Although the electrode is filled with electrolyte, the macroporosity is still distinguished. The macropores are used for supplying gas to all parts of the electrode. The micropores on the other hand are completely filled by the electrolyte. However, it is difficult to know whether the carbonate distribution is the same as when the cell is running. Redistribution of carbonate may occur when the cell is cooled down to room temperature. From the micrograph of the electrode leached in $50 \%$ acetic acid, Fig. 1(b), it is possible to acquire information on the particle size, pore size and agglomerate size. For example, an average diameter of approximately 4-7 $\mu \mathrm{m}$ is estimated for the nickel particles. However, the structure seems to consist of very small particles that are not easily distinguished in the SEM micrographs. Thus, to obtain particle sizes and pore size distribution more accurately, it would be necessary to perform, for example, mercury porosimetry measurements [22].
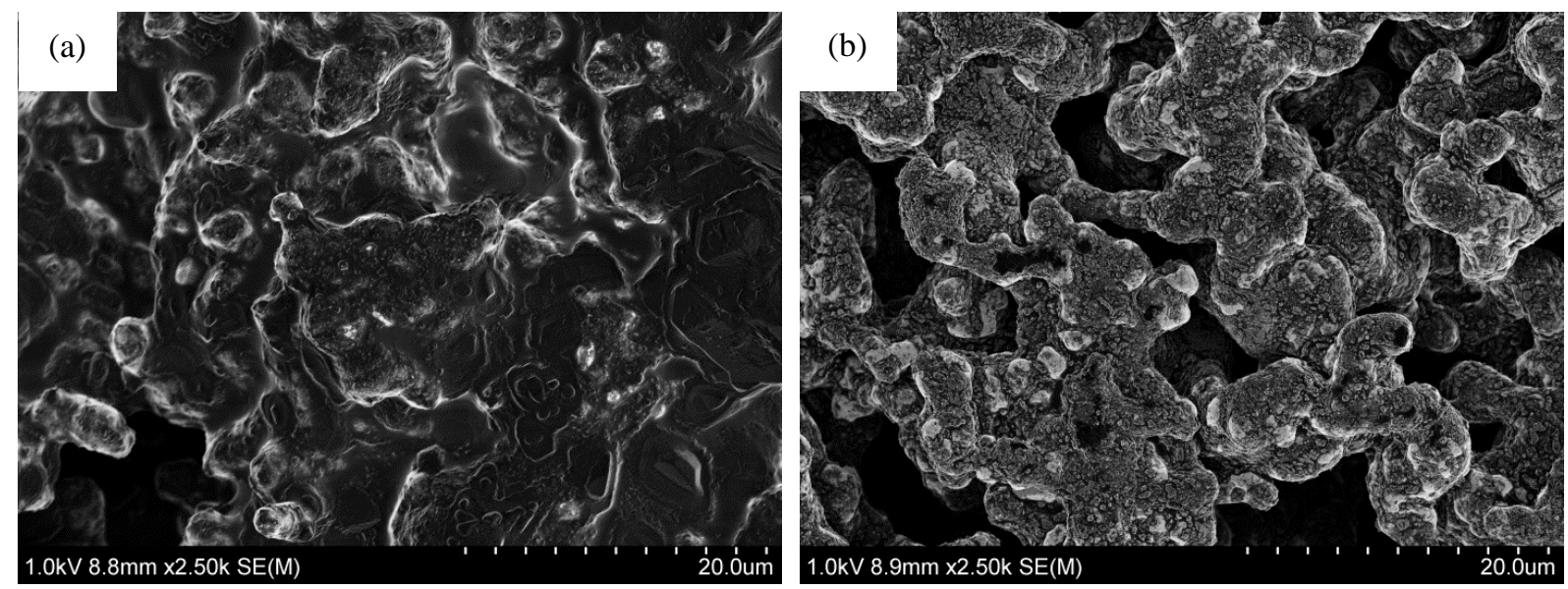

Fig. 1 SEM micrographs of the Ni electrode (a) filled with electrolyte, and (b) leached in 50\% acetic acid. 
The iR-corrected polarization curves of the $\mathrm{Ni}$ electrode are measured in the temperature range of $600-650{ }^{\circ} \mathrm{C}$ for all gas compositions, see Fig. 2. When compared to the reference case, the Ni electrode shows higher polarization losses under the gases with low $\mathrm{H}_{2}$ concentration at all measured temperatures. Using a constant overvoltage of $|50| \mathrm{mV}$, an electrolysis current density of $-0.23 \mathrm{~A} \cdot \mathrm{cm}^{-2}$ is obtained for the reference case at $600{ }^{\circ} \mathrm{C}$, while the values for the hydrogen-lean gases range from -0.15 to $-0.18 \mathrm{~A} \cdot \mathrm{cm}^{-2}$. The Ni electrode polarization decreases when increasing the amount of $\mathrm{CO}_{2}$ and/or $\mathrm{H}_{2} \mathrm{O}$. This is expected, since carbon dioxide and water are reactants in the electrolysis operation $[20,21]$. The polarization curve for the reference case shows a tendency of bending downward at high current densities, which is generally a sign of mass-transfer limitations. However, for the gas consisting of $1 / 49.5 / 49.5 \% \mathrm{H}_{2} / \mathrm{CO}_{2} / \mathrm{H}_{2} \mathrm{O}$ the polarization curve appears to bend upwards at high current densities, not showing any mass-transfer limitations.

As the temperature is increased to $625^{\circ} \mathrm{C}$, the absolute values of electrolysis current densities obtained at the cathodic overvoltage of $50 \mathrm{mV}$ are still lower for the $\mathrm{H}_{2}$-lean gases $\left(0.19-0.25 \mathrm{~A} \cdot \mathrm{cm}^{-2}\right)$ than for the reference case $\left(0.29 \mathrm{~A} \cdot \mathrm{cm}^{-2}\right)$. Due to the different bending directions at high current densities, the polarization curve for the gas containing $25 / 25 / 25 / 25 \mathrm{H}_{2} / \mathrm{CO}_{2} / \mathrm{H}_{2} \mathrm{O} / \mathrm{N}_{2}$ and that for the gas containing $1 / 49.5 / 49.5 \% \mathrm{H}_{2} / \mathrm{CO}_{2} / \mathrm{H}_{2} \mathrm{O}$ intersect at $-0.42 \mathrm{~A} \cdot \mathrm{cm}^{-2}$ and the cathodic overvoltage of $78 \mathrm{mV}$. This implies that lower electrode polarization losses could be obtained under the gas with $1 / 49.5 / 49.5 \%$ $\mathrm{H}_{2} / \mathrm{CO}_{2} / \mathrm{H}_{2} \mathrm{O}$ at high current densities, i.e. $|i|>0.42 \mathrm{~A} \cdot \mathrm{cm}^{-2}$. The same behavior also takes place at $650{ }^{\circ} \mathrm{C}$, where the intersection occurs at a current density of $-0.38 \mathrm{~A} \cdot \mathrm{cm}^{-2}$ and an overvoltage of -56 $\mathrm{mV}$. 

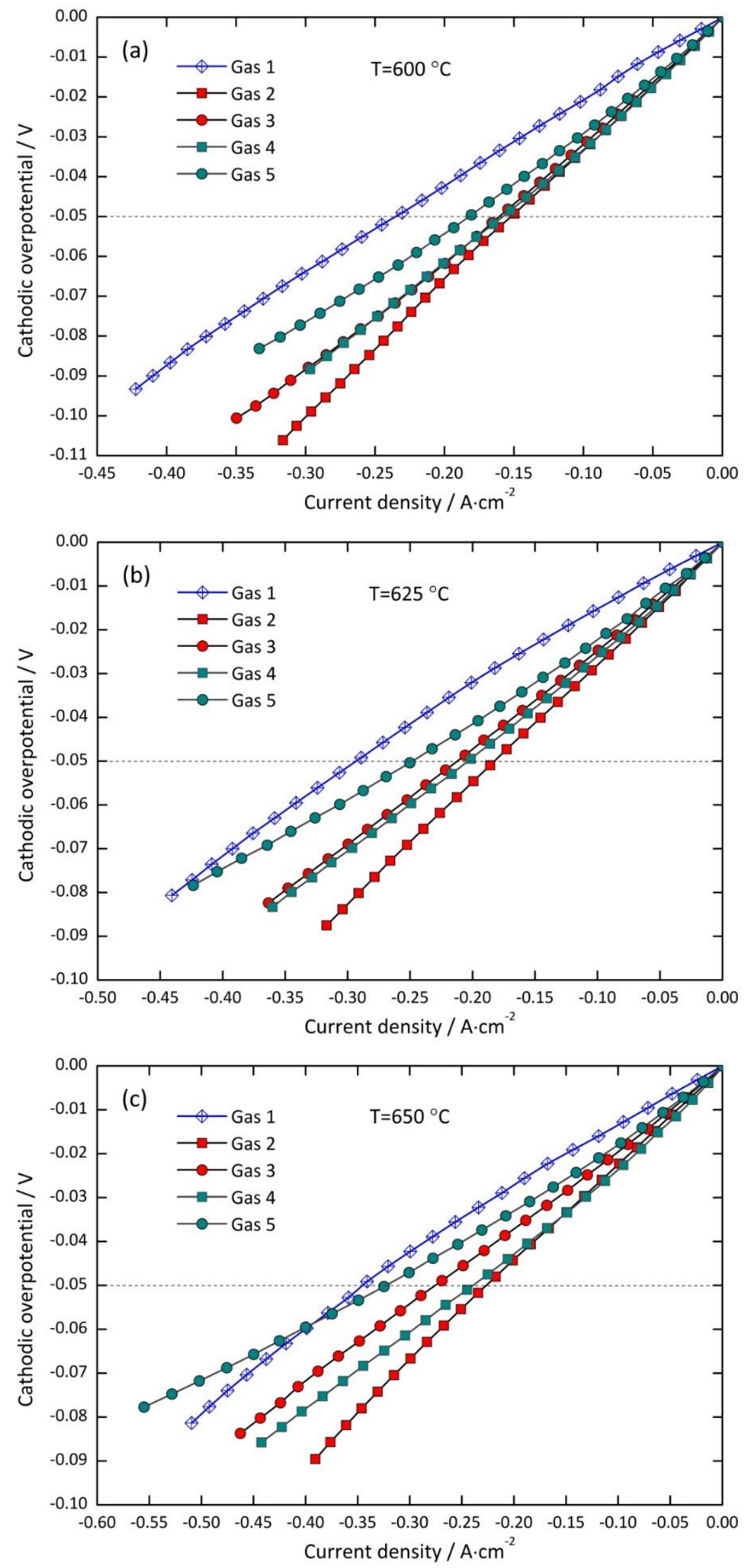

Fig. 2 iR-corrected polarization curves obtained for five different inlet gases in the electrolysis cell. (a) $600{ }^{\circ} \mathrm{C}$, (b) $625{ }^{\circ} \mathrm{C}$ and (c) $650{ }^{\circ} \mathrm{C}$. Gas $1: 25 / 25 / 25 / 25 \% \mathrm{H}_{2} / \mathrm{CO}_{2} / \mathrm{H}_{2} \mathrm{O} / \mathrm{N}_{2}$, gas $2: 1 / 24.5 / 24.5 / 50 \% \mathrm{H}_{2} / \mathrm{CO}_{2} / \mathrm{H}_{2} \mathrm{O} / \mathrm{N}_{2}$, gas 3 : $1 / 49.5 / 24.5 / 25 \% \mathrm{H}_{2} / \mathrm{CO}_{2} / \mathrm{H}_{2} \mathrm{O} / \mathrm{N}_{2}$, gas $4: 1 / 24.5 / 49.5 / 25 \% \mathrm{H}_{2} / \mathrm{CO}_{2} / \mathrm{H}_{2} \mathrm{O} / \mathrm{N}_{2}$, gas 5: $1 / 49.5 / 49.5 \% \mathrm{H}_{2} / \mathrm{CO}_{2} / \mathrm{H}_{2} \mathrm{O}$. 
Fig. 3 shows the impedance spectra of the Ni electrode in electrolysis operation at the temperatures of $600-650{ }^{\circ} \mathrm{C}$. The existence of two arcs is observed in the Nyquist diagrams. The first arc in the high frequency region (at about $20 \mathrm{~Hz}-10 \mathrm{kHz}$ ) corresponds to charge-transfer polarization, while the second arc in the low frequency region (at about $0.01 \mathrm{~Hz}-20 \mathrm{~Hz}$ ) corresponds to mass-transfer polarization [23]. The intercept with the $\mathrm{X}$-axis at the high frequency gives the ohmic loss of the Ni electrode. The ohmic loss, charge-transfer and mass-transfer polarizations obtained from the Nyquist diagrams are shown in Fig. 4. The ohmic losses of the Ni electrode are more or less unaffected by gas composition at all measured temperatures, and the values are estimated to be $0.14,0.10$ and 0.08 $\Omega \cdot \mathrm{cm}^{2}$ at 600,625 and $650{ }^{\circ} \mathrm{C}$, respectively.
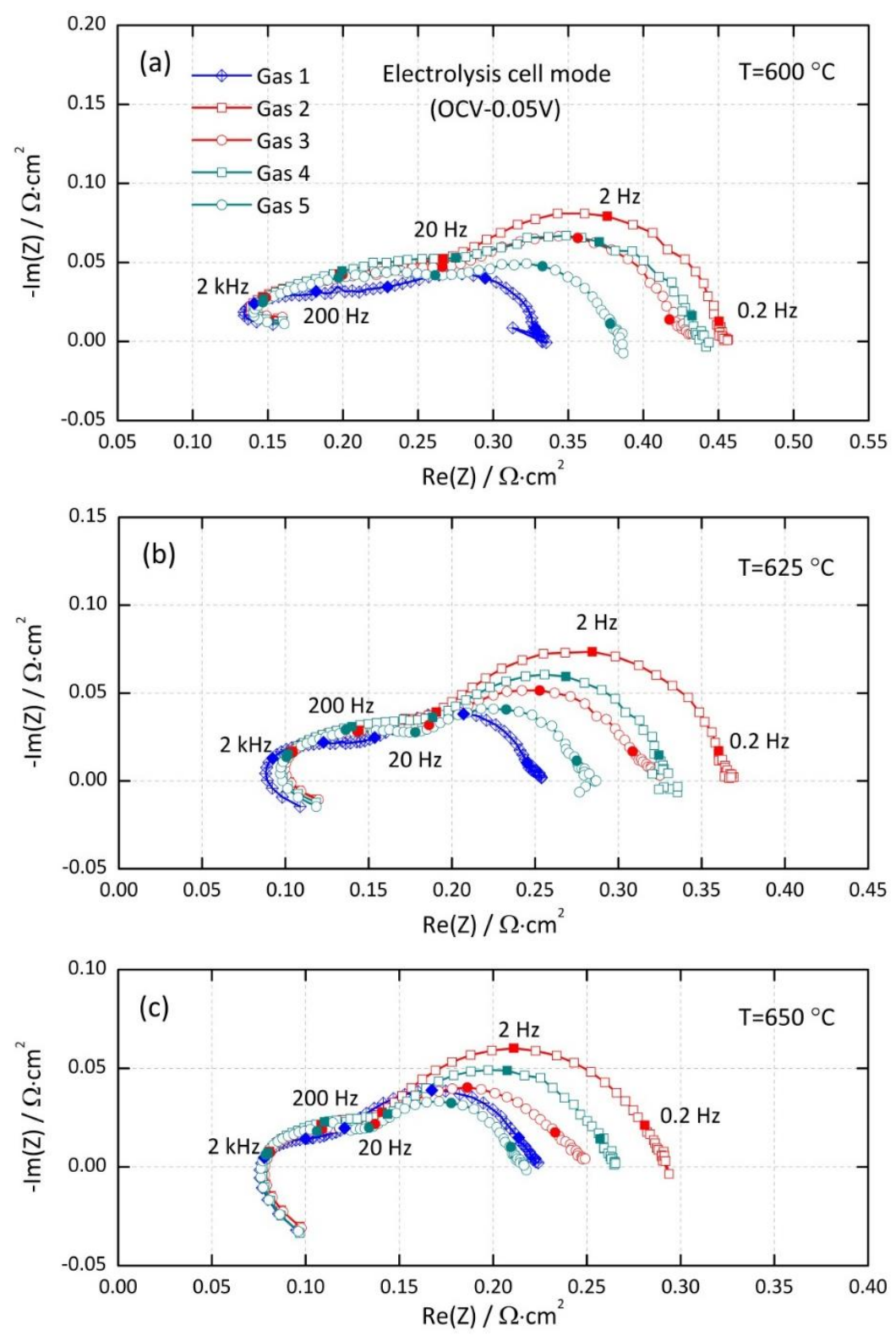

Fig. 3 Nyquist diagrams of the Ni electrode in electrolysis cell mode (OCV-0.05 V), (a) $600{ }^{\circ} \mathrm{C}$, (b) $625^{\circ} \mathrm{C}$ and (c) $650{ }^{\circ} \mathrm{C}$. Gas 1: $25 / 25 / 25 / 25 \% \mathrm{H}_{2} / \mathrm{CO}_{2} / \mathrm{H}_{2} \mathrm{O} / \mathrm{N}_{2}$, gas $2: 1 / 24.5 / 24.5 / 50 \% \mathrm{H}_{2} / \mathrm{CO}_{2} / \mathrm{H}_{2} \mathrm{O} / \mathrm{N}_{2}$, gas $3: 1 / 49.5 / 24.5 / 25 \%$ $\mathrm{H}_{2} / \mathrm{CO}_{2} / \mathrm{H}_{2} \mathrm{O} / \mathrm{N}_{2}$, gas $4: 1 / 24.5 / 49.5 / 25 \% \mathrm{H}_{2} / \mathrm{CO}_{2} / \mathrm{H}_{2} \mathrm{O} / \mathrm{N}_{2}$, gas $5: 1 / 49.5 / 49.5 \% \mathrm{H}_{2} / \mathrm{CO}_{2} / \mathrm{H}_{2} \mathrm{O}$. 
In the Nyquist diagrams, it may be seen that the high-frequency arc shows larger size for gases $2-5$ than for the reference case at all measured temperatures. It indicates that the Ni electrode exhibits a higher charge-transfer polarization as the inlet gases contain low amounts of $\mathrm{H}_{2}$. In Fig. 4(b), for the reference case charge-transfer resistances are $0.095,0.065$ and $0.045 \Omega \cdot \mathrm{cm}^{2}$ at 600,625 and $650{ }^{\circ} \mathrm{C}$, respectively, while the corresponding values for the $\mathrm{H}_{2}$-lean gases are in the ranges of $0.12-0.14$, $0.08-0.09$, and $0.06-0.07 \Omega \cdot \mathrm{cm}^{2}$. In the electrolysis cell the Ni electrode shows relatively slow kinetics when using the inlet gases only containing $1 \% \mathrm{H}_{2}$. Concerning the effect of carbon dioxide or water, it is unexpectedly found that in gases 2-5 an increase of the $\mathrm{CO}_{2}$ or $\mathrm{H}_{2} \mathrm{O}$ concentration from 24.5 to $49.5 \%$ does not significantly decrease the charge-transfer polarization. This is in contrast to the previous conclusion [21] that the electrode kinetics of hydrogen production is strongly dependent on the partial pressure of carbon dioxide or water in the MCEC. But it is necessary to point out that in previous study the inlet gas has a higher amount of hydrogen, being constant at $25 \%$. There are two possible factors that could be an explanation to the contradiction; one is the inaccuracy of the chargetransfer polarization when estimated only according to the frequency region, and the other one is that the effect of carbon dioxide or water on the charge-transfer polarization is probably related to the content of hydrogen in the electrolysis cell. The latter factor is presumably very likely, since the roles played by hydrogen, carbon dioxide and water in the electrolysis cell are complex and most probably affect each other. Despite the previous research to elucidate the electrode kinetics, the reaction mechanism of the Ni electrode for hydrogen production in the MCEC is still not determined [21].

In Fig. 4(c), it is noted that at all measured temperatures the $\mathrm{Ni}$ electrode exhibits a lower masstransfer polarization for the reference case than for $\mathrm{H}_{2}$-lean gases, even though these gases contain higher amounts of carbon dioxide or water (i.e. 49.5\%). This is most likely due to diffusion properties in gas phase. The binary diffusion coefficients for carbon dioxide and water in nitrogen are three or four times lower than in hydrogen. At $650{ }^{\circ} \mathrm{C}$ the binary diffusion coefficients of carbon dioxide in nitrogen and hydrogen are $1.23 \times 10^{-4}$ and $4.18 \times 10^{-4} \mathrm{~m}^{-2} \cdot \mathrm{s}^{-1}$, respectively, while the corresponding values for water are $\mathrm{D}_{\mathrm{H}_{2} \mathrm{ON}}=2.03 \times 10^{-4} \mathrm{~m}^{-2} \cdot \mathrm{s}^{-1}$ and $\mathrm{D}_{\mathrm{H}_{2} \mathrm{OH}_{2}}=6.48 \times$ $10^{-4} \mathrm{~m}^{-2} \cdot \mathrm{s}^{-1}$ [24]. It is not surprising that the lower binary diffusion coefficient might increase the mass-transfer limitations in the gas phase and that this could be an explanation for the higher masstransfer polarization under hydrogen-lean gases observed in Fig. 4(c). However, an exception is shown for the gas consisting of $1 / 49.5 / 49.5 \% \quad \mathrm{H}_{2} / \mathrm{CO}_{2} / \mathrm{H}_{2} \mathrm{O}$ at $650{ }^{\circ} \mathrm{C}$, where a lower mass-transfer polarization, $0.08 \Omega \cdot \mathrm{cm}^{2}$, is obtained when compared to that with the reference case $\left(0.10 \Omega \cdot \mathrm{cm}^{2}\right)$. For gas 5 the amount of reactants is very high and that will decrease the mass-transfer limitations in the reaction. Additionally, more hydrogen will be produced under such operating conditions, thereby improving the diffusion of the reactants in the gas phase. 

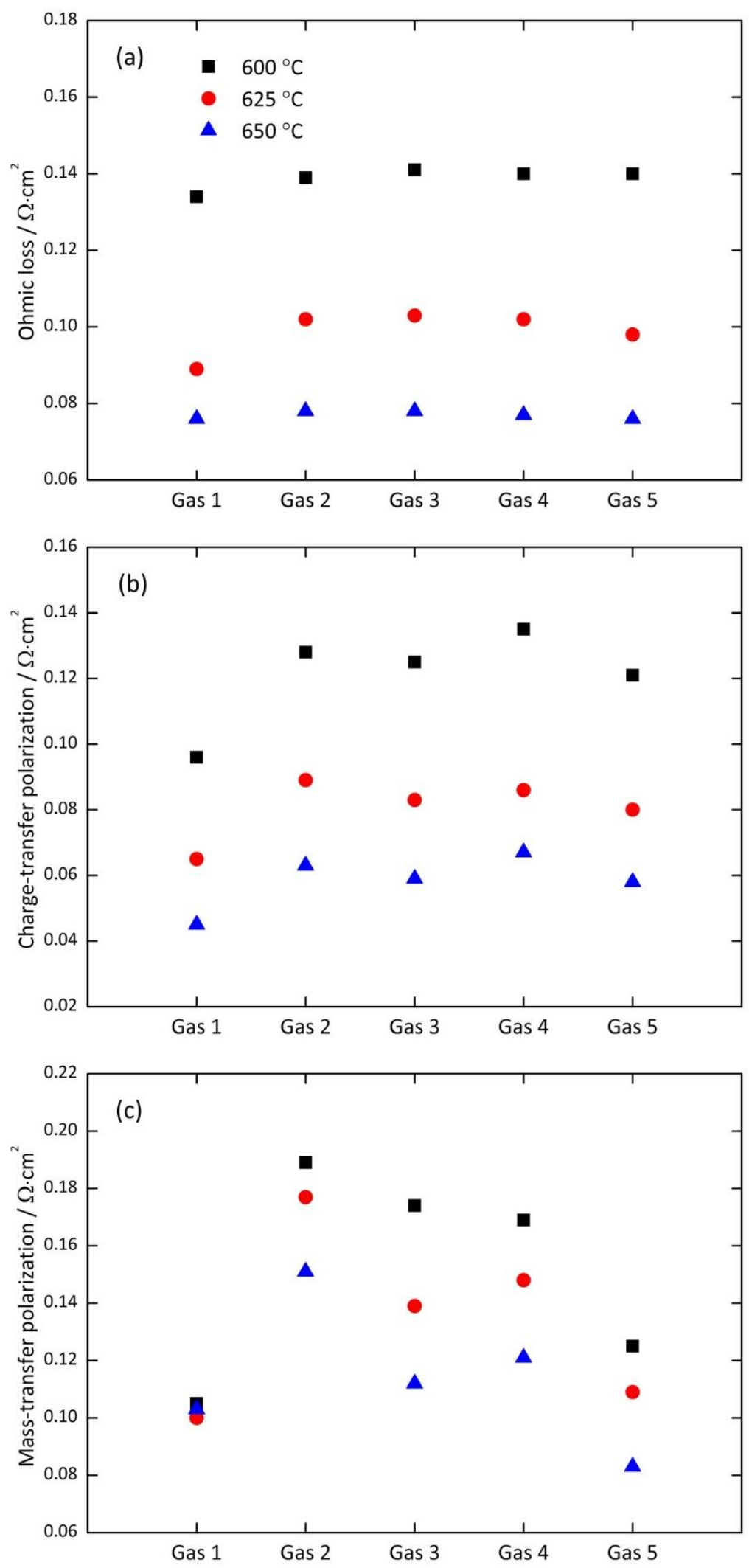

Fig. 4 (a) Ohmic loss, (b) charge-transfer polarization and (c) mass-transfer polarization obtained from the Nyquist diagrams in Fig. 3. Gas 1: 25/25/25/25\% $\mathrm{H}_{2} / \mathrm{CO}_{2} / \mathrm{H}_{2} \mathrm{O} / \mathrm{N}_{2}$, gas 2: 1/24.5/24.5/50\% $\mathrm{H}_{2} / \mathrm{CO}_{2} / \mathrm{H}_{2} \mathrm{O} / \mathrm{N}_{2}$, gas 3: $1 / 49.5 / 24.5 / 25 \% \mathrm{H}_{2} / \mathrm{CO}_{2} / \mathrm{H}_{2} \mathrm{O} / \mathrm{N}_{2}$, gas 4: $1 / 24.5 / 49.5 / 25 \% \mathrm{H}_{2} / \mathrm{CO}_{2} / \mathrm{H}_{2} \mathrm{O} / \mathrm{N}_{2}$, gas 5: $1 / 49.5 / 49.5 \% \mathrm{H}_{2} / \mathrm{CO}_{2} / \mathrm{H}_{2} \mathrm{O}$. 
Regardless of the water concentration, a higher mass-transfer polarization is found for the gases with 24.5\% $\mathrm{CO}_{2}$ (gases 2 and 4) compared to the gases containing 49.5\% $\mathrm{CO}_{2}$ (gases 3 and 5). This indicates that carbon dioxide has a stronger impact on mass-transfer limitations than water in the electrolysis cell. The electrolyte in the MCEC is based on molten carbonate salts and carbon dioxide may play a very complex role in the electrolysis cell. For example, $\mathrm{CO}_{2}$ is a reactant in the production of carbonate ions or when generating $\mathrm{CO}$, and further $\mathrm{CO}_{2}$ is involved in the reverse water-gas shift reaction and other reactions [20]. The observations made in this study show that all components in the gas influence the mass-transfer polarization of the Ni electrode in the electrolysis cell. However, in order to interpret the mass-transfer behavior of the Ni electrode more thoroughly further modeling studies of the MCEC may be needed.

Regarding the low-frequency arc, the arc size is almost unaffected by temperature for the reference case with $25 / 25 / 25 / 25 \% \mathrm{H}_{2} / \mathrm{CO}_{2} / \mathrm{H}_{2} \mathrm{O} / \mathrm{N}_{2}$, and the mass-transfer resistance is more or less constant at $0.10 \Omega \cdot \mathrm{cm}^{2}$ in the temperature range of $600-650{ }^{\circ} \mathrm{C}$, see Fig. 4(c). However, when using inlet gases with low $\mathrm{H}_{2}$ concentration, the size of the low-frequency arc strongly depends on cell temperature. In the molten carbonate electrolysis cell, an increasing amount of hydrogen is produced at the $\mathrm{Ni}$ electrode as the operating temperature is raised. In accordance with the binary diffusion coefficients given above, a higher hydrogen concentration will enable a better reactant diffusion and thereby a decreased mass-transfer polarization. This is also observed for both hydrogen-lean gases when the temperature is raised.

In Fig. 5, the relationship between the polarization resistance $\left(\mathrm{R}_{\mathrm{p}}\right)$ evaluated from the iR-corrected polarization curves and that evaluated from the impedance spectra is shown for the Ni electrode in the MCEC. The slopes of the full polarization curves give the value of $R_{p}$, and in the Nyquist diagrams the electrode polarization is calculated by subtracting the ohmic loss from the total impedance. This graph shows that the polarization resistances recorded by these two techniques are equal for the Ni electrode in the electrolysis cell. 


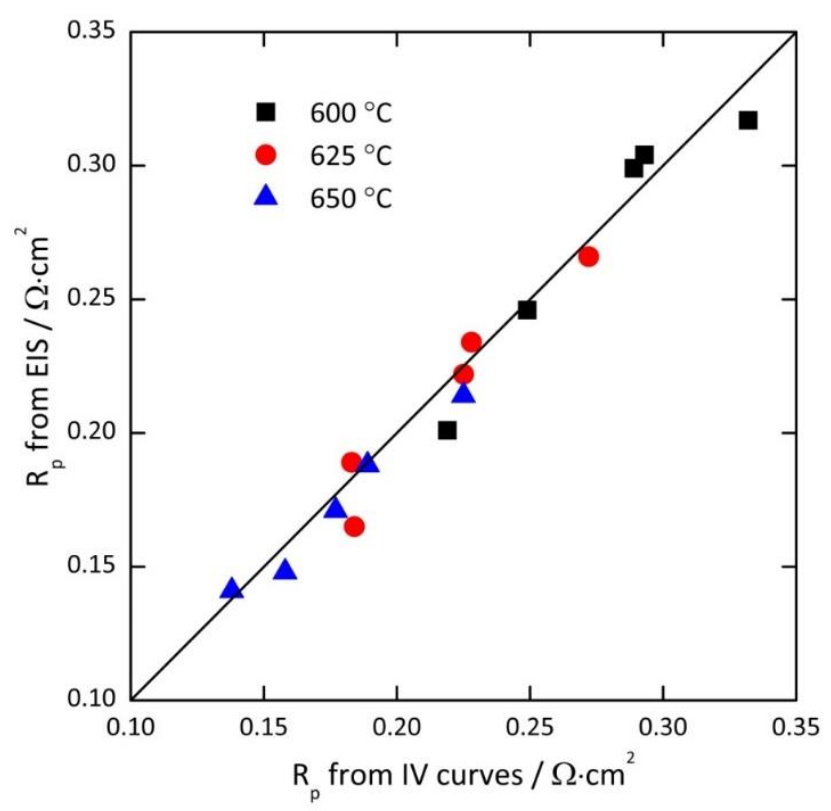

Fig. 5 Relationship between polarization resistances $\left(R_{p}\right)$ obtained from IV curves and impedance spectra for the $\mathrm{Ni}$ electrode in the electrolysis cell. The solid line fits to equal values and symbols refer to measured values.

On the basis of the polarization data in Fig. 2, the exchange current densities are determined using the same theory and method as discussed in the previous study [21]. When analyzing the polarization data for a porous electrode, it is important to take the current distribution into account. Lagergren and Simonsson [25] derived an expression for evaluating the total polarization resistance for a porous electrode. The current-interrupt technique is applied to correct the iR drop, and thus the polarization data does not include the ohmic contribution in this study. In addition, the effective conductivity of the Ni electrode is much higher than that of the electrolyte phase, then a simplified expression (Eq. 1) is obtained for the polarization resistance of the Ni electrode [21, 22].

$$
\frac{d \eta}{d i}=\sqrt{\frac{R T}{n F S i_{0} \kappa}}
$$

where $\kappa$ is the effective conductivity in the electrolyte phase. $S$ is the exterior surface area of the agglomerates, where the dominating part of the electrode reaction takes place.

The effective conductivity of the electrolyte is set to be $5.0 \mathrm{~S} \cdot \mathrm{m}^{-1}$ at $650^{\circ} \mathrm{C}$ [22]. By using the Arrhenius equation [26], the values of $4.1 \mathrm{~S} \cdot \mathrm{m}^{-1}$ and $4.6 \mathrm{~S} \cdot \mathrm{m}^{-1}$ are calculated for the effective electrolyte conductivity at 600 and $625{ }^{\circ} \mathrm{C}$, respectively. The exterior agglomerate surface area, $S$, is estimated to be $2.7 \cdot 10^{5} \mathrm{~m}^{-1}$ by assuming that the agglomerates are spherical and have a radius of approximately $4.5 \mu \mathrm{m}$ [22]. The polarization resistance, $d \eta / d i$, is obtained from the slopes of the polarization curves at low overpotential, i.e. $<40 \mathrm{mV}$. It is assumed that in this low overpotential 
range the $\mathrm{Ni}$ electrode is mainly under kinetic control, where the mass-transfer limitations can be neglected [22].

The exchange current densities calculated for these five inlet gases are shown in Fig. 6. For the reference case the exchange current density increases from 76 to $130 \mathrm{~A} \cdot \mathrm{m}^{-2}$ in the temperature range of $600-650{ }^{\circ} \mathrm{C}$. Lower values are obtained for the $\mathrm{Ni}$ electrode when the inlet gases contain low amounts of hydrogen. In the measured temperature interval, exchange current densities of 31-61, 35-85, 32-62, and 43-114 A. $\mathrm{m}^{-2}$ are obtained for gases 2, 3, 4 and 5, respectively. Since the exchange current density is determined by the rate of charge transfer, this confirms that the Ni electrode kinetics is relatively slow under hydrogen-lean gases.

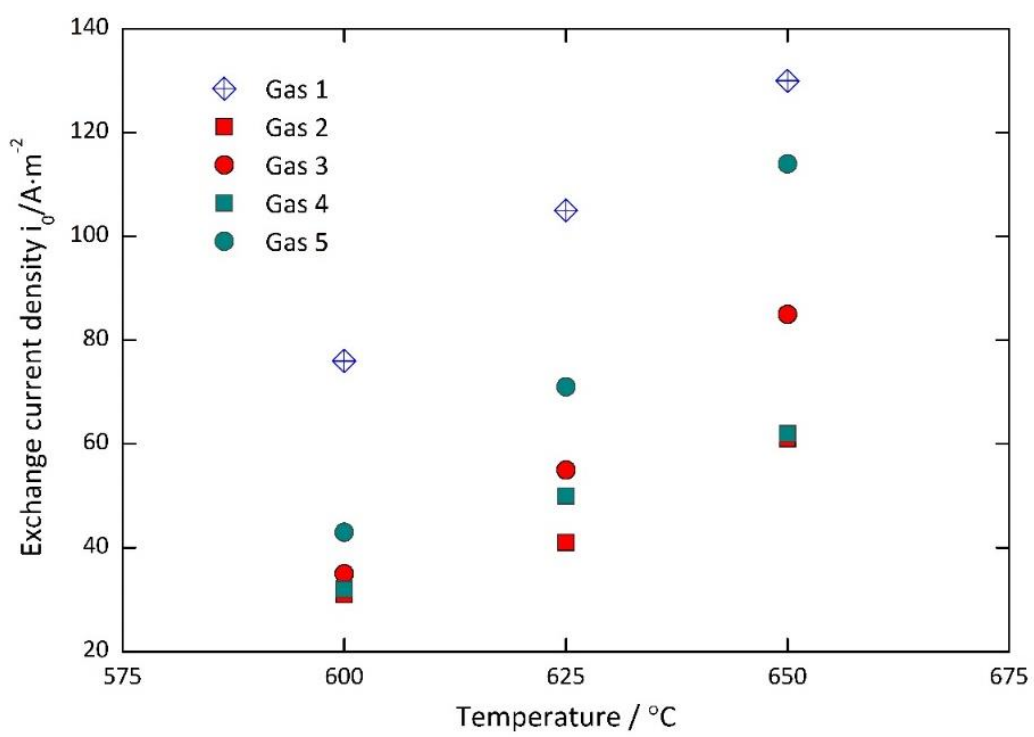

Fig. 6 Exchange current densities as function of temperature for five different gas compositions in the electrolysis cell. Gas 1: $25 / 25 / 25 / 25 \% \mathrm{H}_{2} / \mathrm{CO}_{2} / \mathrm{H}_{2} \mathrm{O} / \mathrm{N}_{2}$, gas $2: 1 / 24.5 / 24.5 / 50 \% \mathrm{H}_{2} / \mathrm{CO}_{2} / \mathrm{H}_{2} \mathrm{O} / \mathrm{N}_{2}$, gas 3 : $1 / 49.5 / 24.5 / 25 \% \mathrm{H}_{2} / \mathrm{CO}_{2} / \mathrm{H}_{2} \mathrm{O} / \mathrm{N}_{2}$, gas $4: 1 / 24.5 / 49.5 / 25 \% \mathrm{H}_{2} / \mathrm{CO}_{2} / \mathrm{H}_{2} \mathrm{O} / \mathrm{N}_{2}$, gas $5: 1 / 49.5 / 49.5 \% \mathrm{H}_{2} / \mathrm{CO}_{2} / \mathrm{H}_{2} \mathrm{O}$.

For hydrogen production at the Ni electrode in the MCEC, the activation energy is calculated to be 69 $\mathrm{kJ} \cdot \mathrm{mol}^{-1}$ for the reference case, using the Arrhenius equation [27]. For the gases with low hydrogen concentration, higher values, 85, 112, 99 and $138 \mathrm{~kJ} \cdot \mathrm{mol}^{-1}$ are obtained for gases 2, 3, 4 and 5, respectively. The result shows that the activation energy is lower for the gases with $24.5 \% \mathrm{CO}_{2}$ (gases 2 and 4) than for the gases with $49.5 \% \mathrm{CO}_{2}$ (gases 3 and 5). The activation energy may be a clue to determining the rate-limiting process [28] and according to the values reported here it seems that the $\mathrm{Ni}$ electrode is under kinetic or mixed control. 


\section{Conclusions}

The polarization losses of the porous Ni electrode in a molten carbonate electrolysis cell were studied using four gases containing low amounts of $\mathrm{H}_{2}$ (i.e. $1 \%$ ) in the temperature range $600-650{ }^{\circ} \mathrm{C}$. When compared to the reference case with the gas containing $25 / 25 / 25 / 25 \% \quad \mathrm{H}_{2} / \mathrm{CO}_{2} / \mathrm{H}_{2} \mathrm{O} / \mathrm{N}_{2}$, higher polarization losses were found for the hydrogen-lean gases.

The electrochemical impedance spectra revealed that in the MCEC the Ni electrode showed a higher charge-transfer polarization for the gases with low hydrogen concentration than for the reference case. The effect of carbon dioxide or water on electrode kinetics was not strong as shown in a previous study [21]. The combined effects of hydrogen, carbon dioxide and water probably influence the $\mathrm{Ni}$ electrode performance in the electrolysis cell. At all measured temperatures the mass-transfer polarization is also higher for $\mathrm{H}_{2}$-lean gases. Except under the condition with $1 / 49.5 / 49.5 \%$ $\mathrm{H}_{2} / \mathrm{CO}_{2} / \mathrm{H}_{2} \mathrm{O}$ at $650{ }^{\circ} \mathrm{C}$, the $\mathrm{Ni}$ electrode exhibited a lower mass-transfer polarization compared to the reference case. It is also noted that for the reference case the mass-transfer polarization was more or less unaffected by temperature. However, when using hydrogen-lean gases it was strongly dependent on temperature. The mass-transfer limitations could probably be affected by diffusion properties in the gas phase.

The exchange current densities confirm that when compared to the reference case the Ni electrode kinetics are slower for the gas containing low amounts of hydrogen in the electrolysis cell. The activation energy, calculated for all measured gas compositions, indicates that the Ni electrode is under kinetic or mixed control.

\section{Acknowledgements}

The financial support of the China Scholarship Council (CSC) is appreciated. The cell components were provided by Ansaldo Fuel Cells in Italy. 


\section{References}

[1] Tao Y, Nishino H, Ashidate S, Kokubo H, Watanabe M, Uchida H. Polarization properties of $\mathrm{La}_{0.6} \mathrm{Sr}_{0.4} \mathrm{Co}_{0.2} \mathrm{Fe}_{0.8} \mathrm{O}_{3}$-based double layer-type oxygen electrodes for reversible SOFCs. Electrochim Acta 2009;54:3309-15.

[2] Kelly NA. Hydrogen production by water electrolysis. In: Basile A, Ilulianelli A, editors. Advances in Hydrogen Production, Storage and Distribution, Woodhead Publishing; 2014; p. 159-85. DOI: 10.1533/9780857097736.2.159.

[3] Marina OA, Pederson LR, Williams MC, Coffey GW, Meinhardt KD, Nguyen CD, Thomsen EC. Electrode performance in reversible solid oxide fuel cells. J Electrochem Soc 2007;154:B452-9.

[4] Dönitz W, Erdle E. High-temperature electrolysis of water vapor-status of development and perspectives for application. Int J Hydrogen Energy 1985;10:291-5.

[5] Laguna-Bercero M A. Recent advances in high temperature electrolysis using solid oxide fuel cells: A review. J Power Sources 2012;203:4-16.

[6] O’Brien JE, Stoots CM, Herring JS, Hartvigsen J. Hydrogen production performance of a 10-cell planar solid-oxide electrolysis stack. J Fuel Cell Sci Tech 2006;3:213-9.

[7] O’Brien JE, McKellar MG, Harvego EA, Stoots CM. High-temperature electrolysis for large-scale hydrogen and syngas production from nuclear energy - summary of system simulation and economic analyses, Int J Hydrogen Energy 2010;35:4808-19.

[8] Nguyen VN, Fang QP, Packbier U, Blum L. Long-term tests of a Jülich planar short stack with reversible solid oxide cells in both fuel cell and electrolysis modes, Int J Hydrogen Energy 2013;38:4281-90.

[9] Milobar DG, Hartvigsen JJ, Elangovan S. A techno-economic model of a solid oxide electrolysis system. Faraday Discuss 2015;182:329-39.

[10] Ebbesen SD, Graves C, Mogensen M. Production of synthetic fuels by co-electrolysis of steam and carbon dioxide. Int J Green Energy 2009;6:646-60.

[11] Graves C, Ebbesen SD, Mogensen M. Co-electrolysis of $\mathrm{CO}_{2}$ and $\mathrm{H}_{2} \mathrm{O}$ in solid oxide cells: Performance and durability. Solid State Ionics 2011;192:398-403.

[12] Kim-Lohsoontorn P, Bae J. Electrochemical performance of solid oxide electrolysis cell electrodes under high-temperature coelectrolysis of steam and carbon dioxide. J Power Sources 2011;196:7161-8. 
[13] Becker WL, Braun RJ, Penev M, Melaina M. Production of Fischer-Tropsch liquid fuels from high temperature solid oxide co-electrolysis units. Enegy 2012;47:99-115.

[14] Torrell M, García-Rodríguez, Morata A, Penelas G, Tarancón. Co-electrolysis of steam and CO2 in full-ceramic symmetrical SOECs: a strategy for avoiding the use of hydrogen as a safe gas. Faraday Discuss 2015;182:227-39.

[15] Peelen WHA, Hemmes K, de Wit JHW. $\mathrm{CO}_{2}$ reduction in molten $62 / 38$ mole\% $\mathrm{Li} / \mathrm{K}$ carbonate mixture. Electrochim Acta 1997;43:763-9.

[16] Kaplan V, Wachtel E, Gartsman K, Feldman Y, Lubomirsky I. Conversion of $\mathrm{CO}_{2}$ to $\mathrm{CO}$ by electrolysis of molten lithium carbonate. J Electrochem Soc 2010;157:B552-6.

[17] Kaplan V, Wachtel E, Lubomirsky I. Titanium carbide coating of titanium by cathodic deposition from a carbonate melt. J Electrochem Soc 2012;159:E159-61.

[18] Chery D, Albin V, Lair V, Cassir M. Thermodynamic and experimental approach of electrochemical reduction of $\mathrm{CO}_{2}$ in molten carbonates. Int J Hydrogen Energy 2014;39:12330-9.

[19] Chery D, Lair V, Cassir M. $\mathrm{CO}_{2}$ electrochemical reduction into $\mathrm{CO}$ or $\mathrm{C}$ in molten carbonates: a thermodynamic point of view. Electrochim Acta 2015;160:74-81.

[20] Hu L, Rexed I, Lindbergh G, Lagergren C. Electrochemical performance of reversible molten carbonate fuel cells. Int J Hydrogen Energy 2014;39:12323-9.

[21] Hu L, Lindbergh G, Lagergren C. Electrode kinetics of the Ni porous electrode for hydrogen production in a molten carbonate electrolyis cell (MCEC). J Electrochem Soc 2015;162:F1020-8.

[22] Lindbergh G, Olivry M, Sparr M. Experimental investigation of the porous nickel anode in the molten carbonate fuel cell. J Electrochem Soc 2001;148:A411-7.

[23] Yoshikawa M, Bodén A, Sparr M, Lindbergh G. Experimental determination of effective surface area and conductivities in the porous anode of moten carbonate fuel cell. J Power Sources 2006;158:94-102.

[24] Bird RB, Stewart WE, Lightfoot EN. Tansport phenomena. 2rd ed. New York: J. Wiley \& Sons; 2002.

[25] Lagergren C, Simonsson D. The effects of oxidant gas compositions on the polarization of porous $\mathrm{LiCoO}_{2}$ electrodes for the molten carbonate fuel cell. J Electrochem Soc 1997;144:3813-8.

[26] Tanase S, Miyazaki Y, Yanagida M, Tanimoto K, Kodama T. Conductance measurements in molten alkali carbonates. Prog Batt Sol Cells 1987;6:195-200. 
[27] Ang PGP, Sammells AF. Influence of electrolyte composition on electrode kinetics in the molten carbonate fuel cell. J Electrochem Soc 1980;127:1287-94.

[28] Yuh CY, Selman JR. The polarization of molten carbonate fuel cell electrodes I. Analysis of steady-state porlarization data. J Electrochem Soc 1991;138:3642-8. 